\title{
Sources of anions in aerosols in northeast Greenland during late winter
}

\author{
M. Fenger ${ }^{1}$, L. L. Sørensen ${ }^{2,3}$, K. Kristensen ${ }^{1}$, B. Jensen ${ }^{2}$, Q. T. Nguyen $^{1,2}$, J. K. Nøjgaard ${ }^{2}$, A. Massling ${ }^{2}$, H. Skov Sk, $^{2,3}$, \\ T. Becker ${ }^{2}$, and M. Glasius ${ }^{1}$ \\ ${ }^{1}$ Department of Chemistry and iNANO, Aarhus University, 8000 Aarhus, Denmark \\ ${ }^{2}$ Department of Environmental Science, Aarhus University, 4000 Roskilde, Denmark \\ ${ }^{3}$ Arctic Research Centre, Aarhus University, 8000 Aarhus, Denmark \\ ${ }^{4}$ Institute of Chemical Engineering, Biotechnology and Environmental Technology, University of Southern Denmark, \\ 5230 Odense M, Denmark
}

Correspondence to: L. L. Sørensen (1ls@ dmu.dk)

Received: 4 March 2012 - Published in Atmos. Chem. Phys. Discuss.: 11 June 2012

Revised: 17 December 2012 - Accepted: 8 January 2013 - Published: 7 February 2013

\begin{abstract}
The knowledge of climate effects of atmospheric aerosols is associated with large uncertainty, and a better understanding of their physical and chemical properties is needed, especially in the Arctic environment. The objective of the present study is to improve our understanding of the processes affecting the composition of aerosols in the high Arctic. Therefore size-segregated aerosols were sampled at a high Arctic site, Station Nord (Northeast Greenland), in March 2009 using a Micro Orifice Uniform Deposit Impactor. The aerosol samples were extracted in order to analyse three water-soluble anions: chloride, nitrate and sulphate. The results are discussed based on possible chemical and physical transformations as well as transport patterns.

The total concentrations of the ions at Station Nord were $53-507 \mathrm{ng} \mathrm{m}^{-3}, 2-298 \mathrm{ng} \mathrm{m}^{-3}$ and $535-1087 \mathrm{ng} \mathrm{m}^{-3}$ for chloride $\left(\mathrm{Cl}^{-}\right)$, nitrate $\left(\mathrm{NO}_{3}^{-}\right)$and sulphate $\left(\mathrm{SO}_{4}^{2-}\right)$, respectively. The aerosols in late winter/early spring, after polar sunrise, are found to be a mixture of long-range transported and regional to local originating aerosols. Fine particles, smaller than $1 \mu \mathrm{m}$, containing $\mathrm{SO}_{4}^{2-}, \mathrm{Cl}^{-}$and $\mathrm{NO}_{3}^{-}$, are hypothesized to originate from long-range transport, where $\mathrm{SO}_{4}^{2-}$ is by far the dominating anion accounting for 50 $85 \%$ of the analyzed mass. The analysis suggests that $\mathrm{Cl}^{-}$ and $\mathrm{NO}_{3}^{-}$in coarser particles $(>1.5 \mu \mathrm{m})$ originate from lo$\mathrm{cal} /$ regional sources. Under conditions where the air mass is transported over sea ice at high wind speeds, very coarse particles $(>18 \mu \mathrm{m})$ are observed, and it is hypothesized that frost flowers on the sea ice are a source of the very coarse nitrate particles.
\end{abstract}

\section{Introduction}

The changing climate is of increasing concern among politicians, scientists and the general population. There are still many important climatic subjects, where our understanding is insufficient (IPCC, 2007). The largest temperature increase, due to climate change, is observed in the high Arctic, where the observed temperature increase is twice as high as at mid-latitudes, and the increase is expected to continue in the future (ACIA, 2004; Quinn et al., 2008). Therefore an enhanced understanding of the climate dynamics in this particular area is highly needed; however measurements and studies of the atmospheric chemistry at the high Arctic are still very limited due to its remote location and the small number of sites where measurements are made.

The presence of aerosols in the atmosphere affects the environment in multiple ways. One of the most significant effects is the scattering of incoming solar radiation resulting in a net cooling of air; thereby offsetting part of the global warming induced by greenhouse gases (Haywood and Boucher, 2000; Jacobson, 2001). However, climate forcing from aerosols still requires focus and in-depth studies since it is one of the largest uncertainties in predicting future climate by models according to the Intergovernmental Panel on Climate Change (IPCC, 2007). These studies are complicated by the fact that the physical and chemical properties of aerosols are highly variable in both time and space.

Aerosols contain a number of chemically different species, and the effect of individual particle properties on the 
scattering efficiency of an atmospheric layer depends on the size segregated chemical composition of the atmospheric aerosol. Water-soluble inorganic anions strongly determine the sub-saturated growth of particles under atmospheric conditions, and their ability to form clouds (e.g. Swietlicki et al., 2008).

About three decades ago, it was discovered, that a considerable part of the Arctic atmosphere becomes highly polluted during winter because of the accumulation of Eurasian pollutants, creating what became generally known as "Arctic haze" (Flyger et al., 1980; Barrie et al., 1981; Heidam et al., 2004; Glasow and Crutzen, 2007). Arctic haze aerosols consist primarily of sulphate $\left(\mathrm{SO}_{4}^{2-}\right)$ and particulate organic matter in addition to ammonium $\left(\mathrm{NH}_{4}^{+}\right)$, nitrate $\left(\mathrm{NO}_{3}^{-}\right)$and black carbon (BC) (e.g. Li and Barrie, 1993; Quinn et al., 2002). The Arctic haze phenomenon results in a characteristic annual variation of $\mathrm{SO}_{4}^{2-}, \mathrm{NO}_{3}^{-}$and anthropogenically derived elements (e.g. Heidam et al., 2004; Quinn et al., 2007). Concentrations of aerosols in high Arctic air (Polissar et al., 2001) and snow (Douglas and Sturm, 2004) are at their highest during late winter and early spring when anthropogenic pollution is most efficiently transported from lower latitudes (e.g. Heidam, et al., 2004). Thus combustion sources at other continents influence and partly determine the composition of the aerosols observed in the high Arctic. Late winter and early spring is also accompanied by significant increases in the amount of solar radiation reaching the surface and initiating the photochemistry in the Arctic atmosphere and at/in the snowpack. Photochemistry in the snowpack can result in production of e.g. $\mathrm{NO}_{\mathrm{x}}$ which can be emitted from the snow into the atmosphere (Domine and Shepson, 2002; Grannas et al., 2007), where photochemical oxidation of gases can lead to formation of secondary aerosols such as $\mathrm{NO}_{3}^{-}$and $\mathrm{SO}_{4}^{2-}$ (Barrie and Hoff, 1984; Grannas et al., 2007). Therefore both long-range transport and local processes influence the composition of Arctic aerosols, and subsequently the system becomes very complex. As a consequence it is important to obtain a better understanding of the physical and chemical dynamics of the particles in the Arctic region.

Studies at Station Nord have reported $\mathrm{SO}_{\mathrm{x}}$ $\left(\mathrm{SO}_{\mathrm{x}}=\mathrm{SO}_{2}+\mathrm{SO}_{4}^{2-}\right)$ and total $\mathrm{NO}_{3}^{-}$(total $\mathrm{NO}_{3}^{-}=\mathrm{NO}_{3}^{-}$ particle $+\mathrm{HNO}_{3}$ gas) with a typical Arctic haze pattern (Heidam et al., 1999; Heidam et al., 2004, Nguyen et al., 2013). Reported weekly concentrations of total $\mathrm{NO}_{3}^{-}$during a study period from 1990-2001 range from a few $\mathrm{ng} \mathrm{m}^{-3}$ to approximately $130 \mathrm{ng} \mathrm{m}^{-3}$ in March while reported weekly mean concentrations of $\mathrm{SO}_{\mathrm{x}}$ for the same period were up to $750 \mathrm{ng} \mathrm{m}^{-3}$ (Heidam et al., 2004). A recent study by Nguyen et al. (2013) for the period from March 2008-February 2010 has indicated the Siberian industries as the largest sources of total $\mathrm{SO}_{\mathrm{x}}$ while $\mathrm{Cl}^{-}$was mostly attributed to marine sources.

In this paper we present the size fractionated main inorganic anion components: $\mathrm{Cl}^{-}, \mathrm{NO}_{3}^{-}$and $\mathrm{SO}_{4}^{2-}$ in aerosols measured at a high Arctic site in northeast Greenland. The sampling of size-segregated aerosols was performed shortly after polar sunrise. The objective is to improve the understanding of the processes influencing the chemical composition of aerosols in the high Arctic atmosphere by discussing the results as a function of sources, physical and chemical transformations, and transport patterns.

\section{Method}

\subsection{Logistics}

Atmospheric measurements were carried out at Station Nord the first time in the late 1970s (Flyger et al., 1980) and have taken place continuously since the late 1990s (Heidam et al., 2004). Station Nord is located in a remote area in northeast Greenland at $81^{\circ} 36^{\prime} \mathrm{N}, 16^{\circ} 40^{\prime} \mathrm{W}$ (Fig. 1a). It is a small military installation inhabited by a permanent staff of five, and with relatively few guests (scientists and others) throughout the year, mainly during summer.

The sampling site, Flygers Hut, is located approximately $2 \mathrm{~km}$ south of the main building complex at an altitude of $25 \mathrm{~m}$ a.s.l. (Fig. 1b). The area is a fairly flat peninsula of about $10 \mathrm{~km} \times 10 \mathrm{~km}$. During winter Station Nord is recurrently exposed to Eurasian air masses coming from northern and eastern directions (Heidam et al., 1999).

Aerosols were sampled from 5 to 24 March 2009 just after polar sunrise. The length of the days increased rapidly, with the sun above the horizon for a few minutes in the beginning of the sampling period, to $20 \mathrm{~h}$ a day in the end. Throughout the sampling period the temperature was on average $-40^{\circ} \mathrm{C}$, varying between $-18^{\circ} \mathrm{C}$ and $-45^{\circ} \mathrm{C}$. The wind speed ranged between 1 and $8 \mathrm{~m} \mathrm{~s}^{-1}$, except during the night of 13 March, on 16-17 March and on 21 March when the wind speed reached $10 \mathrm{~m} \mathrm{~s}^{-1}$. The measurement of wind speed at Station Nord is carried out by the use of cup anemometers, which often freeze at low temperatures and therefore the uncertainty of wind speed measurements is large. Here we use reanalysis data from NCEP/DOE AMIP-II (Kanamitsu et al., 2002) for wind speed estimates at 1000 mbar (Fig. 2) recognizing that these data are also associated with large uncertainty, especially in the Arctic. Comparing reanalysis data to measured data, using a sonic anemometer (METEK-USA) in spring 2011 (Fig. S1), shows weak correlation $(R=0.38)$. However the measured and modelled data generally show the same trend in the magnitude of the wind speed. The wind speed data are estimated at 1000 mbar and the ground pressure was at times lower during the measurement campaign, yet a comparison of wind speeds for 1000, 925 and 800 mbar shows no big difference in the wind speed.

\subsection{Sampling and analysis}

The collection of size-segregated aerosols was conducted by a Micro Orifice Uniform Deposit Impactor (MOUDI), MSP 


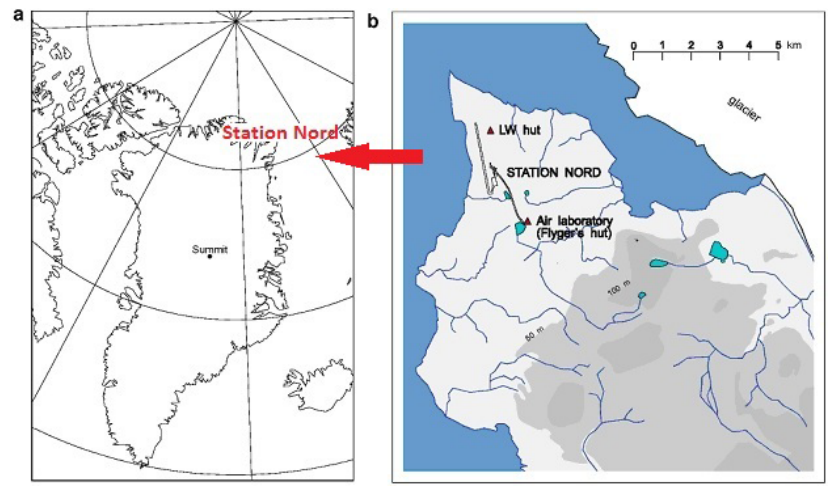

Fig. 1. (a) Greenland with the location of Station Nord and (b) the position of the air monitoring site Flyger's Hut at Station Nord (Heidam et al., 1999).

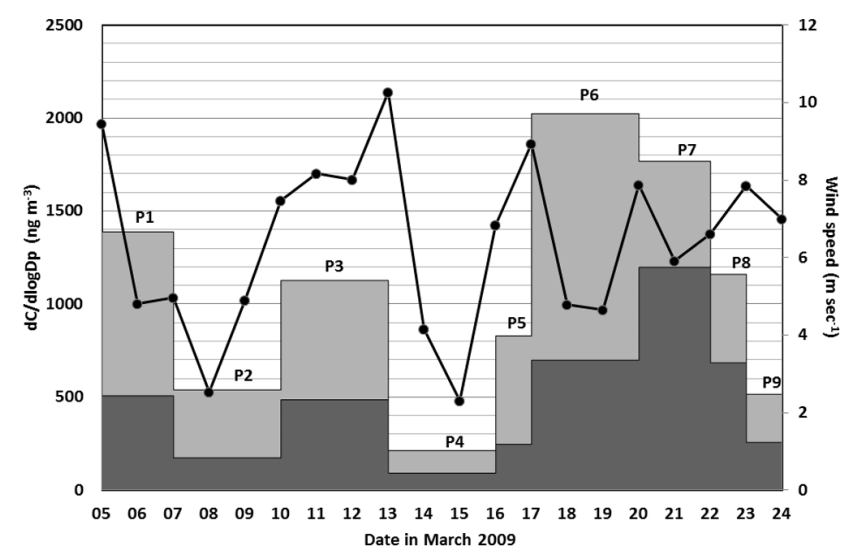

Fig. 2. Particle mass collected by the MOUDI during the different sampling periods (Px) in March 2009 shown for particles where $D>1.8 \mu \mathrm{m}$ (dark grey) and $D<1.8 \mu \mathrm{m}$ (light grey). The 24-h mean wind speed $\left(\mathrm{m} \mathrm{s}^{-1}\right)$ at Long $16.5^{\circ} \mathrm{W}$ Lat $81.5^{\circ} \mathrm{N}$ is also shown as dots connected by a curve. The wind data are reanalysis data from NCEP/DOE AMIP II.

Corporation, Model 110-R at a flow rate of $30 \mathrm{~L} \mathrm{~min}^{-1}$. The sampler was operated with 11 fractionation stages, and the aerodynamic cut-off diameters (particle sizes corresponding to $50 \%$ collection efficiency) of the stages are $18,10.0,5.6$, $3.2,1.8,1.00,0.56,0.32,0.18,0.100$ and $0.056 \mu \mathrm{m}$. In order to reduce particle bouncing the aluminium sampling foils were coated with silicone spray before sampling. The foils were changed 9 times during the collection period and the length of each sample period varied from 22 to $71 \mathrm{~h}$. Sample blanks were included for each collection period. This was represented by a foil that was handled like a sample foil, except that it was not placed in the MOUDI. The aerosol samples were stored in clean plastic vials and shipped to the laboratory in Denmark under freezing conditions. In the laboratory samples were stored in darkness at $-20^{\circ} \mathrm{C}$ until analysis.
The MOUDI foils were ultrasonically extracted in $6 \mathrm{~mL}$ distilled water for $2 \mathrm{~h}$. The extracts were filtered with a syringe filter $(0.22 \mu \mathrm{m}$ pore size $)$ followed by analysis of the major anions: $\mathrm{Cl}^{-}, \mathrm{NO}_{3}^{-}$and $\mathrm{SO}_{4}^{2-}$ using a Metrohm suppressed ion chromatography system. A Metrosep A Supp 5-250 column was used with an eluent of $3.2 \mathrm{mM}$ $\mathrm{Na}_{2} \mathrm{CO}_{3} / 1.0 \mathrm{mM} \mathrm{NaHCO}$. An auto-sampler was used to introduce $20 \mu \mathrm{L}$ of sample into the eluent maintained at a flow rate of $0.7 \mathrm{~mL} \mathrm{~min}^{-1}$. In addition, blank foils were extracted for each analysis and the blank concentrations were subtracted from the sample values. Detection limits for each stage were $0.55 \mathrm{ng} \mathrm{m}^{-3}$ for $\mathrm{Cl}^{-}, 0.40 \mathrm{ng} \mathrm{m}^{-3}$ for $\mathrm{NO}_{3}^{-}$, and $0.32 \mathrm{ng} \mathrm{m}^{-3}$ for $\mathrm{SO}_{4}^{2-}$ for three-day sampling and three times higher for one-day sampling periods. The size intervals of the sampled aerosol are not equally distributed; thus in order to illustrate the aerosol size distribution the concentration of particles is normalized. The normalized concentrations $\mathrm{d} C / \mathrm{d} \log D_{\mathrm{p}}$ are given by Eq. (1).

$\frac{\mathrm{d} C}{\mathrm{~d} \log D_{\mathrm{p}}}=\frac{C}{\log \sqrt{\frac{d_{\mathrm{p}, \text { biggerthan }}}{d_{\mathrm{p}, \text { smallerthan }}}}}$

where $C$ is the concentration found on the stage, and $d_{\mathrm{p}}$ is the diameter for the stage size boundaries used.

A Scanning Mobility Particle Sizer (SMPS, Model: TSI DMA 3081, TSI CPC 3010) was operated during the MOUDI sampling periods. The SMPS inlet was connected to the station inlet system, which is operated by drawing an air flow of $1 \mathrm{~m}^{3} \mathrm{~min}^{-1}$ through a stainless steel tubing system with a diameter of $0.10 \mathrm{~m}$ into the hut. This inlet has no cut-off for atmospheric particles. The SMPS sampling time was set to $2.5 \mathrm{~min}$. and data were further averaged for the corresponding MOUDI sampling periods. Based on the obtained particle number size distributions, the particle volume size distributions were calculated in the size regime between 10 and $400 \mathrm{~nm}$, assuming spherical particles. The average particle mass concentration for the campaign period is $1044 \mathrm{ng} \mathrm{m}^{-3}$ when using an average particle density of $1.7 \mathrm{~g} \mathrm{~cm}^{-3}$.

During the field campaign, concentrations of $\mathrm{NO}_{\mathrm{x}}\left(\mathrm{NO}_{2}\right.$ and NO) were estimated as half-hour mean based on continuous measurements using a chemiluminiscent monitor (API NOx analyzer, model 200AU) at a precision of $5 \%$ and a detection limit of $150 \mathrm{ppt}$. The gas was sampled at a flow rate of $1 \mathrm{~L} \mathrm{~min}^{-1}$ and the monitor was calibrated once a week using $345 \mathrm{ppb}$ NO gas and zero gas was added around 02:00 every night. The $\mathrm{NO}_{\mathrm{x}}$ concentration during the field campaign is shown in Fig. 3.

\section{Results and discussion}

Table 1 displays the concentrations of the major ions $\left(\mathrm{Cl}^{-}\right.$, $\mathrm{NO}_{3}^{-}$and $\mathrm{SO}_{4}^{2-}$ ) for 11 size segregated stages of MOUDI samples. The total concentrations for each sampling period 


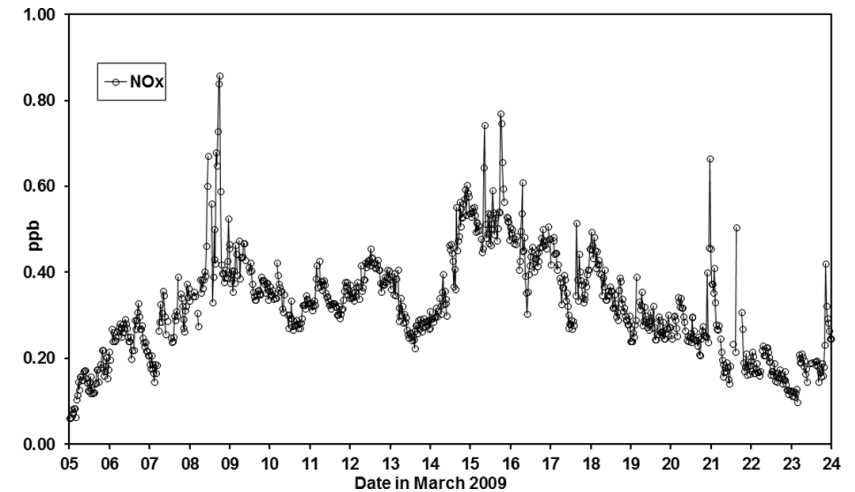

Fig. 3. Atmospheric concentrations of $\mathrm{NO}_{\mathrm{x}}(\mathrm{ppb})$ at Station Nord measured as half hour mean during the field campaign in March 2009.

range between 53 and $507 \mathrm{ng} \mathrm{m}^{-3}, 2-298 \mathrm{ng} \mathrm{m}^{-3}$ and 535$1087 \mathrm{ng} \mathrm{m}^{-3}$ for $\mathrm{Cl}^{-}, \mathrm{NO}_{3}^{-}$and $\mathrm{SO}_{4}^{2-}$, respectively, and contribute to about $6-39 \%, 0.3-25 \%$ and $50-85 \%$ of the analyzed mass. The standard deviation ranges between 4 and $15 \mathrm{ng} \mathrm{m}^{-3}$ for $\mathrm{Cl}^{-}$, between 4 and $14 \mathrm{ng} \mathrm{m}^{-3}$ for $\mathrm{NO}_{3}^{-}$and between 7 and $25 \mathrm{ng} \mathrm{m}^{-3}$ for $\mathrm{SO}_{4}^{2-}$. The measured concentrations are comparable to findings observed at other Arctic sites e.g. at Alert and Svalbard (Kawamura et al., 2007; Teinila et al., 2003). The normalized size-segregated mass distributions of $\mathrm{SO}_{4}^{2-}, \mathrm{Cl}^{-}$, and $\mathrm{NO}_{3}^{-}$are shown in Figs. 4, 5 and 6.

Several parameters are important with respect to aerosol mass concentration, particle number concentration and size distribution. These include emission strengths, short- and long-range transport, meteorological conditions and physical as well as chemical processes, which control the formation of secondary aerosols and their changes at a later stage.

Submicron particles from 0.1 to $1 \mu \mathrm{m}$ constitute the main mass of long-range transported particles (Seinfeld and Pandis, 2006) and a large part of the particles we collected are associated with this size fraction. The Hybrid Single Particle Lagrangian Integrated Trajectory (HYSPLIT) model was used to generate air-mass back trajectories in order to estimate the history of the observed aerosols. Back trajectories were calculated arriving at 50 and $500 \mathrm{~m}$ a.s.l. every $12 \mathrm{~h}$ (Fig. 7).

From the back trajectories, three main classes of air mass origin were observed during the sampling period: (1) west of Station Nord (Canada and West Greenland (P1 and P2) and (2) north of Station Nord (the North Pole and Siberia (P3, P4, P8 and P9)) and (3) along the coast of North Greenland, Alert and North Pole (P5, P6 and P7) (see Figs. 2 and 7). For spatial reference the corresponding sea ice coverage and the continents are provided as background maps, showing first-yearice (FYI) and multi-year-ice (MYI). Both background maps are retrieved from data provided by the Jet Propulsion Laboratory (JPL) and Brigham Young University (BYU). The
Table 1. Concentrations $\left(\mathrm{ng} \mathrm{m}^{-3}\right)$ of ions in the size-segregated aerosol samples.

\begin{tabular}{|c|c|c|c|c|c|c|}
\hline Date & ID & $\begin{array}{c}\text { Size } \\
\mu \mathrm{m}\end{array}$ & $\mathrm{Cl}$ & $\mathrm{NO}_{3}$ & $\mathrm{SO}_{4}$ & $\begin{array}{l}\text { Total } \\
\text { anions }\end{array}$ \\
\hline $5-7$ & P1-01 & 18 & 19.0 & 13.4 & 19.3 & 51.6 \\
\hline \multirow[t]{11}{*}{ March } & $\mathrm{P} 1-02$ & 10 & 10.0 & 9.1 & 2.1 & 21.2 \\
\hline & P1-03 & 5.6 & 8.56 & 7.2 & 0.5 & 16.3 \\
\hline & P1-04 & 3.2 & 20.4 & 9.9 & 3.7 & 34.0 \\
\hline & $\mathrm{P} 1-05$ & 1.8 & 69.5 & 24.5 & 19.2 & 113.1 \\
\hline & P1-06 & 1 & 87.1 & 38.6 & 27.9 & 153.7 \\
\hline & P1-07 & 0.56 & 79.5 & 39.3 & 81.1 & 199.9 \\
\hline & P1-08 & 0.32 & 27.1 & 21.4 & 290.2 & 338.7 \\
\hline & P1-09 & 0.18 & 12.4 & 12.0 & 83.9 & 108.3 \\
\hline & $\mathrm{P} 1-10$ & 0.1 & 7.4 & 6.9 & 7.8 & 22.1 \\
\hline & $\mathrm{P} 1-11$ & 0.056 & 6.9 & 10.2 & $<\mathrm{DG}$ & 16.8 \\
\hline & & Total & 347.7 & 192.5 & 535.4 & \\
\hline $7-10$ & P2-01 & 18 & 14.5 & 6.8 & 9.6 & 30.9 \\
\hline \multirow[t]{11}{*}{ March } & P2-02 & 10 & 7.4 & 2.4 & 9.1 & 18.9 \\
\hline & P2-03 & 5.6 & 2.2 & 1.7 & ¡DG & 3.3 \\
\hline & P2-04 & 3.2 & 4.4 & 5.4 & 1.5 & 11.3 \\
\hline & P2-05 & 1.8 & 15.1 & 12.3 & 11.1 & 38.5 \\
\hline & P2-06 & 1 & 24.0 & 20.5 & 17.7 & 62.2 \\
\hline & P2-07 & 0.56 & 45.2 & 47.7 & 82.1 & 175.1 \\
\hline & P2-08 & 0.32 & 10.9 & 13.6 & 316.0 & 340.5 \\
\hline & P2-09 & 0.18 & 4.5 & 5.3 & 106.1 & 115.9 \\
\hline & $\mathrm{P} 2-10$ & 0.1 & 2.2 & 2.0 & 11.44 & 15.7 \\
\hline & P2-11 & 0.056 & 4.4 & 5.8 & 1.81 & 12.0 \\
\hline & & Total & 134.8 & 123.4 & 565.9 & \\
\hline $10-13$ & P3-01 & 18 & 12.7 & 5.6 & 9.4 & 27.6 \\
\hline \multirow[t]{11}{*}{ March } & P3-02 & 10 & 3.2 & 1.6 & 0.3 & 5.1 \\
\hline & P3-03 & 5.6 & 4.2 & 1.6 & $<\mathrm{DL}$ & 5.8 \\
\hline & P3-04 & 3.2 & 21.1 & 6.4 & 7.6 & 35.1 \\
\hline & P3-05 & 1.8 & 80.9 & 23.0 & 37.6 & 141.5 \\
\hline & P3-06 & 1 & 78.7 & 31.6 & 57.3 & 167.6 \\
\hline & P3-07 & 0.56 & 48.6 & 23.0 & 160.0 & 231.6 \\
\hline & P3-08 & 0.32 & 17.2 & 6.7 & 473.5 & 497.5 \\
\hline & P3-09 & 0.18 & 10.3 & 6.9 & 175.0 & 192.2 \\
\hline & P3-10 & 0.1 & 3.4 & 2.5 & 22.0 & 27.9 \\
\hline & P3-11 & 0.056 & 2.5 & 2.1 & 7.0 & 11.7 \\
\hline & & Total & 282.9 & 111.0 & 949.6 & \\
\hline $13-16$ & P4-01 & 18 & 3.6 & 3.0 & 2.4 & 8.9 \\
\hline \multirow[t]{11}{*}{ March } & P4-02 & 10 & 2.4 & 2.0 & ¡DL & 4.3 \\
\hline & P4-03 & 5.6 & 2.3 & 2.6 & 1.5 & 6.4 \\
\hline & P4-04 & 3.2 & 4.2 & 3.6 & 1.4 & 9.2 \\
\hline & P4-05 & 1.8 & 10.5 & 9.4 & 7.6 & 27.5 \\
\hline & P4-06 & 1 & 10.2 & 12.5 & 12.9 & 35.6 \\
\hline & P4-07 & 0.56 & 8.7 & 16.4 & 83.1 & 108.2 \\
\hline & P4-08 & 0.32 & 2.9 & 4.3 & 427.1 & 434.3 \\
\hline & P4-09 & 0.18 & 2.6 & 6.3 & 136.6 & 145.5 \\
\hline & $\mathrm{P} 4-10$ & 0.1 & 2.2 & 2.5 & 13.3 & 18.0 \\
\hline & P4-11 & 0.056 & 3.4 & 2.3 & 2.3 & 7.9 \\
\hline & & Total & 53.0 & 64.9 & 688.0 & \\
\hline
\end{tabular}

data have been obtained by the SeaWinds instruments on board the QuikSCAT satellite (Lungu, 2001). SeaWinds was 
Table 1. Continued.

\begin{tabular}{|c|c|c|c|c|c|c|}
\hline Date & ID & $\begin{array}{l}\text { Size } \\
\mu \mathrm{m}\end{array}$ & $\mathrm{Cl}$ & $\mathrm{NO}_{3}$ & $\mathrm{SO}_{4}$ & $\begin{array}{r}\text { Total } \\
\text { anions }\end{array}$ \\
\hline $16-17$ & P5-01 & 18 & 17.0 & 10.4 & 7.9 & 35.4 \\
\hline \multirow[t]{11}{*}{ March } & P5-02 & 10 & 7.0 & 19.7 & ¡DL & 25.2 \\
\hline & P5-03 & 5.6 & 7.8 & 40.1 & ¡DL & 47.9 \\
\hline & P5-04 & 3.2 & 10.0 & 42.7 & 0.3 & 52.8 \\
\hline & P5-05 & 1.8 & 20.0 & 22.4 & 5.3 & 47.7 \\
\hline & P5-06 & 1 & 34.6 & 59.4 & 13.8 & 107.9 \\
\hline & P5-07 & 0.56 & 52.7 & 29.1 & 94.4 & 176.2 \\
\hline & P5-08 & 0.32 & 16.7 & 12.3 & 441.7 & 470.7 \\
\hline & P5-09 & 0.18 & 11.1 & 16.9 & 104.0 & 132.0 \\
\hline & P5-10 & 0.1 & 15.1 & 8.5 & 9.644 & 33.2 \\
\hline & P5-11 & 0.056 & 15.5 & 36.8 & ¡DL & 52.1 \\
\hline & & Total & 207.4 & 298.4 & 675.4 & \\
\hline $17-20$ & P6-01 & 18 & 32.8 & 5.5 & 5.8 & 44.1 \\
\hline \multirow[t]{11}{*}{ March } & P6-02 & 10 & 3.9 & 2.0 & ¡DL & 5.6 \\
\hline & P6-03 & 5.6 & 3.0 & 2.6 & $<\mathrm{DL}$ & 5.2 \\
\hline & P6-04 & 3.2 & 20.2 & 3.7 & 2.1 & 26.0 \\
\hline & P6-05 & 1.8 & 115.8 & 12.4 & 17.3 & 145.5 \\
\hline & P6-06 & 1 & 149.9 & 23.4 & 31.8 & 205.1 \\
\hline & P6-07 & 0.56 & 140.7 & 29.2 & 108.4 & 278.3 \\
\hline & P6-08 & 0.32 & 22.7 & 6.2 & 393.6 & 422.5 \\
\hline & P6-09 & 0.18 & 12.2 & 5.2 & 117.9 & 135.2 \\
\hline & P6-10 & 0.1 & 3.9 & 2.8 & 13.7 & 20.4 \\
\hline & P6-11 & 0.056 & 2.4 & 2.6 & 2.0 & 6.9 \\
\hline & & Total & 507.6 & 95.4 & 692.0 & \\
\hline $20-22$ & P7-01 & 18 & 154.2 & 29.8 & 58.1 & 242.1 \\
\hline \multirow[t]{11}{*}{ March } & P7-02 & 10 & 19.0 & 5.2 & 4.0 & 28.2 \\
\hline & P7-03 & 5.6 & 6.1 & 4.2 & $<\mathrm{DL}$ & 10.7 \\
\hline & P7-04 & 3.2 & 33.3 & 7.2 & 6.1 & 46.6 \\
\hline & P7-05 & 1.8 & 88.8 & 22.4 & 27.8 & 139.0 \\
\hline & P7-06 & 1 & 73.6 & 32.5 & 40.7 & 146.7 \\
\hline & P7-07 & 0.56 & 53.7 & 32.4 & 169.3 & 255.5 \\
\hline & P7-08 & 0.32 & 5.0 & 4.0 & 620.8 & 629.8 \\
\hline & P7-09 & 0.18 & 4.2 & 4.2 & 145.5 & 153.8 \\
\hline & P7-10 & 0.1 & 3.3 & 3.4 & 11.3 & 17.9 \\
\hline & P7-11 & 0.056 & 3.4 & 2.8 & 3.7 & 9.9 \\
\hline & & Total & 444.5 & 148.1 & 1087.6 & \\
\hline $22-23$ & P8-01 & 18 & 27.7 & 2.6 & 5.1 & 35.4 \\
\hline \multirow[t]{11}{*}{ March } & P8-02 & 10 & 10.6 & 6.1 & $<\mathrm{DL}$ & 15.6 \\
\hline & P8-03 & 5.6 & 17.6 & $<\mathrm{DL}$ & $<\mathrm{DL}$ & 13.4 \\
\hline & P8-04 & 3.2 & 33.2 & $<\mathrm{DL}$ & 6.7 & 40.9 \\
\hline & P8-05 & 1.8 & 82.7 & 22.5 & 30.4 & 135.5 \\
\hline & P8-06 & 1 & 57.5 & 28.1 & 39.1 & 124.6 \\
\hline & P8-07 & 0.56 & 27.9 & 20.6 & 179.6 & 228.1 \\
\hline & P8-08 & 0.32 & 6.9 & 10.8 & 605.1 & 622.8 \\
\hline & P8-09 & 0.18 & 7.2 & $<\mathrm{DL}$ & 122.8 & 125.4 \\
\hline & P8-10 & 0.1 & 11.8 & $<\mathrm{DL}$ & 8.0 & 14.0 \\
\hline & P8-11 & 0.056 & 8.2 & $<\mathrm{DL}$ & $<\mathrm{DL}$ & 1.3 \\
\hline & & Total & 291.3 & 70.9 & 994.8 & \\
\hline
\end{tabular}

an active microwave radar scatterometer launched in June 1999 and operative until November 2009. Apparent brightness temperature for each scatterometer pulse was modelled
Table 1. Continued.

\begin{tabular}{llcrrrr}
\hline Date & ID & $\begin{array}{c}\text { Size } \\
\mu \mathrm{m}\end{array}$ & $\mathrm{Cl}$ & $\mathrm{NO}_{3}$ & $\mathrm{SO}_{4}$ & $\begin{array}{r}\text { Total } \\
\text { anions }\end{array}$ \\
\hline 23-24 & P9-01 & 18 & 11.6 & $<\mathrm{DL}$ & $<\mathrm{DL}$ & 5.3 \\
March & P9-02 & 10 & 8.2 & $<\mathrm{DL}$ & $<\mathrm{DL}$ & 1.9 \\
& P9-03 & 5.6 & 7.0 & $<\mathrm{DL}$ & $<\mathrm{DL}$ & 7.8 \\
& P9-04 & 3.2 & 15.1 & 6.0 & 5.9 & 27.0 \\
& P9-05 & 1.8 & 22.0 & 4.9 & 16.4 & 43.35 \\
& P9-06 & 1 & 16.8 & 4.6 & 20.5 & 41.9 \\
& P9-07 & 0.56 & 10.9 & $<\mathrm{DL}$ & 111.1 & 121.2 \\
& P9-08 & 0.32 & 8.9 & $<\mathrm{DL}$ & 321.0 & 328.0 \\
& P9-09 & 0.18 & 8.1 & 4.1 & 70.0 & 82.2 \\
& P9-10 & 0.1 & 11.4 & $<\mathrm{DL}$ & 36.3 & 46.3 \\
& P9-11 & 0.056 & 8.7 & $<\mathrm{DL}$ & 22.7 & 29.6 \\
& & Total & 129.1 & 2.1 & 603.4 & \\
\hline
\end{tabular}

from the instrument noise measurements, providing information of open water and ice (JPL, 2006). The data quality is sufficient to distinguish between first-year-ice (FYI) and multi-year-ice (MYI). Sea ice classification and extraction of the continents was carried out in ArcGIS (ESRI, 2011) based on gridded polar-stereographic Level 3 Sigma-0 QuikSCAT data over the Arctic Polar region. The three classes of air masses are all characterized by transport over sea ice and/or snow covered terrestrial areas, however, transport over sea ice was longer during the sampling periods $\mathrm{P} 3, \mathrm{P} 4, \mathrm{P} 8$ and $\mathrm{P} 9$ and according to the HYSPLIT trajectories the atmosphere also seemed to have less vertical mixing for those periods indicating more stable stratification.

Sources of local pollution can be considered to be negligible because of the remote location and the minimum of influence from inhabitants at Station Nord throughout the year.

The particle mass size distributions of $\mathrm{SO}_{4}^{2-}$ have a predominant mode in the fine fraction $(1 \mu \mathrm{m})$, peaking approximately at a mean geometric diameter $\left(D_{\mathrm{g}}\right)$ of $0.32 \mu \mathrm{m}$. In contrast to $\mathrm{Cl}^{-}$and $\mathrm{NO}_{3}^{-}$the $\mathrm{SO}_{4}^{2-}$ mass size distributions are constant in terms of shape but not magnitude. This suggests that the majority of the $\mathrm{SO}_{4}^{2-}$ is long range-transported and originates from combustion sources, which also supports previous conclusions from Heidam et al. (2004) and is in agreement with the correlation between $\mathrm{SO}_{4}^{2-}$ and black carbon at Alert (Gong et al., 2010). $\mathrm{SO}_{4}^{2-}$ is by far the dominating anion during the collection period. This size may have a considerable climatic effect depending on its mixing state with other species, since visible solar radiation is scattered very efficiently within this size range (Wallace and Hobbs, 2006). The coarser mode $(>1 \mu \mathrm{m}) \mathrm{SO}_{4}^{2-}$ particles, found with smaller mass concentrations, may originate from sea spray and/or $\mathrm{SO}_{4}^{2-}$ formed on coarse sea salt or soil particles via oxidation of $\mathrm{SO}_{2}$ (Barrie and Hoff, 1984). The large particle size suggests that this is not long-range transported but is originating from a nearby source. The contribution from sea salt sulphate $\left(\mathrm{ss}^{-} \mathrm{SO}_{4}^{2-}\right.$ ) at Station Nord is 

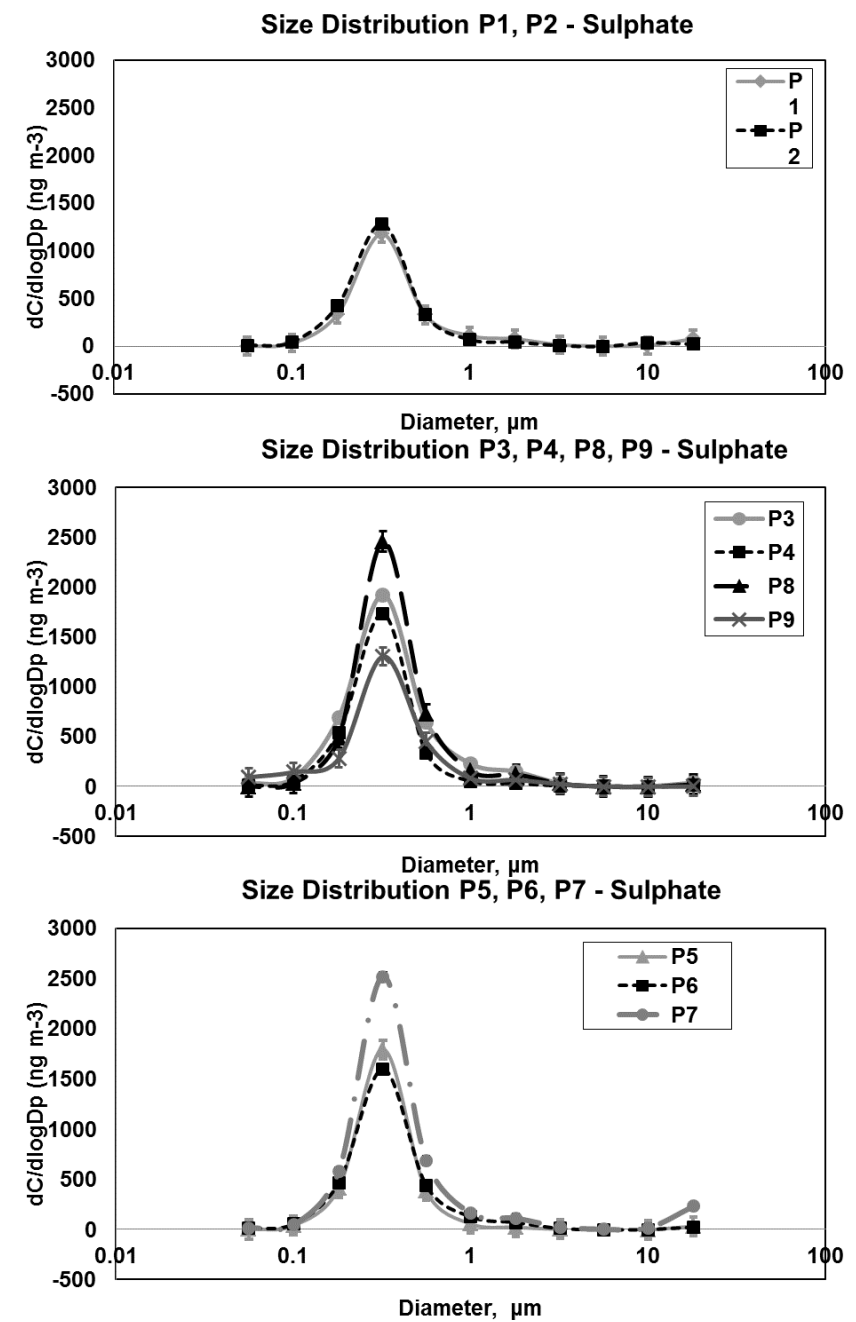

Fig. 4. Normalized size-segregated mass distribution of $\mathrm{SO}_{4}^{2-}$ during the sampling periods P1-P9 listed in Table 1.

small according to Heidam et al. (2004), which is consistent with other studies (Rankin et al., 2002), where it was found that sulphate is depleted in freezing ice due to formation of mirabilite $\left(\mathrm{Na}_{2} \mathrm{SO}_{4} \cdot 10 \mathrm{H}_{2} \mathrm{O}\right)$. Studies in Alaska have found about $30 \%$ of the total mass being $\mathrm{SO}_{4}^{2-}$ in Arctic aerosols during winter-time (Barrie et al., 1981), but observations by Frossard et al. (2011), during a cruise in the Arctic ocean showed that non-sea salt sulphate represents $61 \%$ of the total particle mass $<1 \mu \mathrm{m}$. Our data set shows, that the mass fraction of $\mathrm{SO}_{4}^{2-}$ in the size range $56-560 \mathrm{~nm}$ comprise around $60 \%$ of the total aerosol mass, which is calculated based on SMPS measurements. This is estimated as an average for the whole campaign, but for the periods P3 and P4 the masses obtained from the SMPS measurements are smaller than the masses of the anions sampled by the MOUDI. The particle density used in the SMPS based calculations is set to $1.7 \mathrm{~g} \mathrm{~cm}^{-3}$ due to an overall dominance of $\mathrm{SO}_{4}^{2-}$ for the whole campaign. Submicron $\mathrm{SO}_{4}^{2-}$ particles
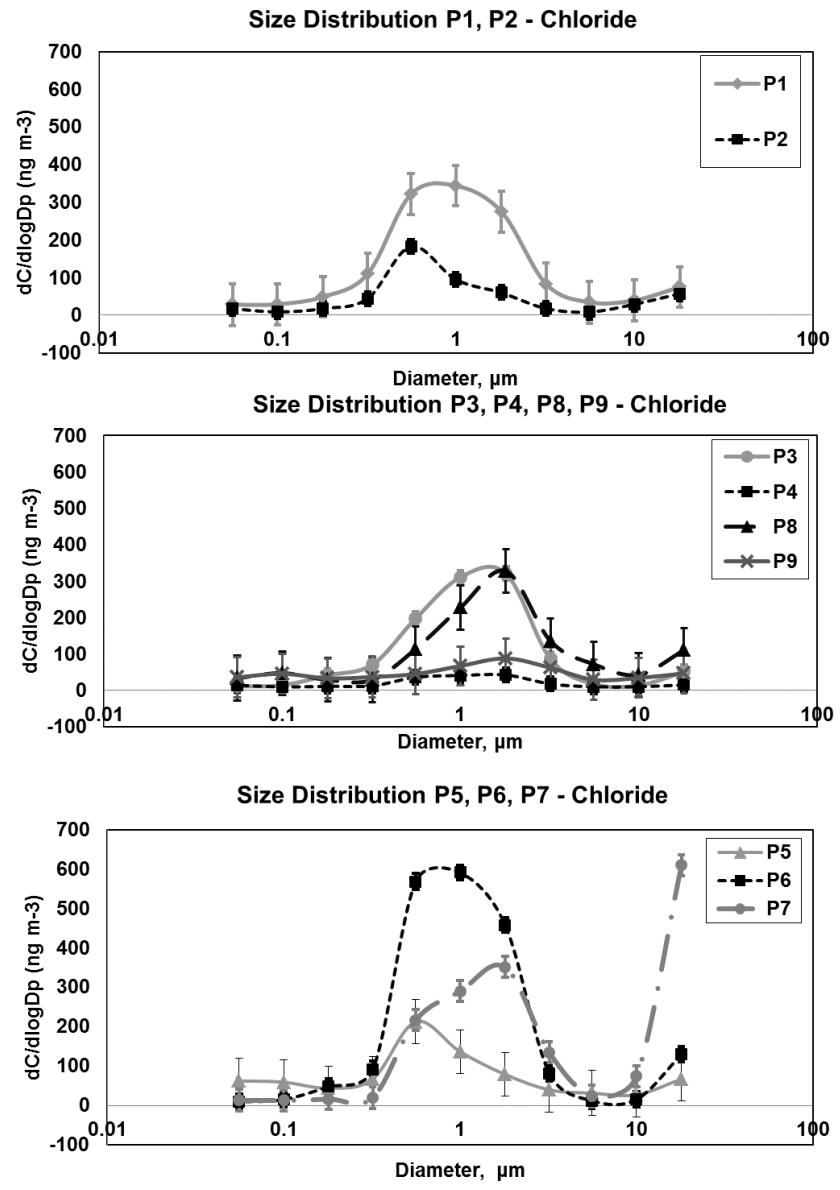

Fig. 5. Normalized size-segregated mass distribution of $\mathrm{Cl}^{-}$during the sampling periods P1-P9 listed in Table 1.

consist primarily of non-sea-salt sulphate formed by gas-toparticle conversion of the photo-oxidation products of e.g. $\mathrm{SO}_{2}$ and dimethylsulphide. However P3 and $\mathrm{P} 4$ are originating from the sea ice and are likely to have a large content of sea salt, which have a higher density $\left(2.2 \mathrm{~g} \mathrm{~cm}^{-3}\right)$. If we leave out the measurement periods originating from the sea ice, then $\mathrm{SO}_{4}^{2-}$ constitute $48 \%$ of the total air mass. These numbers are a higher fraction than observed by Barrie et al. (1981) but in accordance with the numbers found by Frossard et al. (2011).

As described previously, Station Nord is placed on a peninsula and surrounded by sea. The fact that the surrounding ocean was covered with ice during the sampling period excludes the likelihood of atmospheric direct sea spray emissions reaching Station Nord. The lifetime of coarse aerosols is confined due to gravitational settling so only aerosols with diameters slightly below $1 \mu \mathrm{m}$ make their way to Station Nord from distant sources. The ice-cover extent does not change considerably during the sampling period in the Arctic area, thus the distance from the sampling site to open water remains constant at approximately $1000 \mathrm{~km}$ during the field study. The size distributions of $\mathrm{Cl}^{-}$and $\mathrm{NO}_{3}^{-}$differ overall 


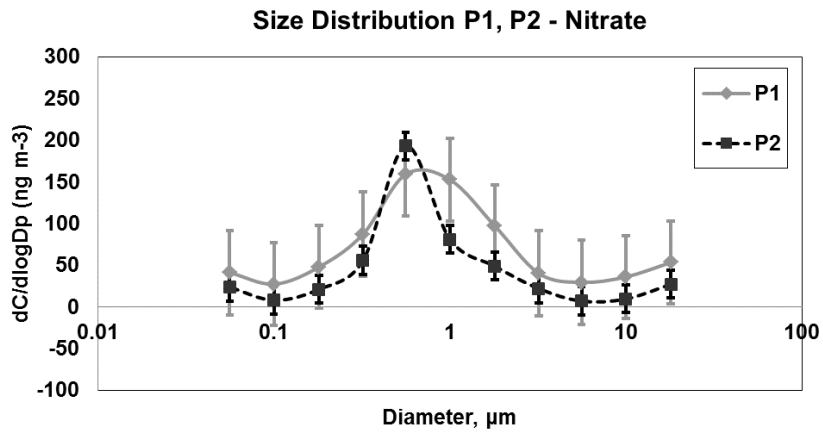

Size Distribution P3, P4, P8, P9 - Nitrate
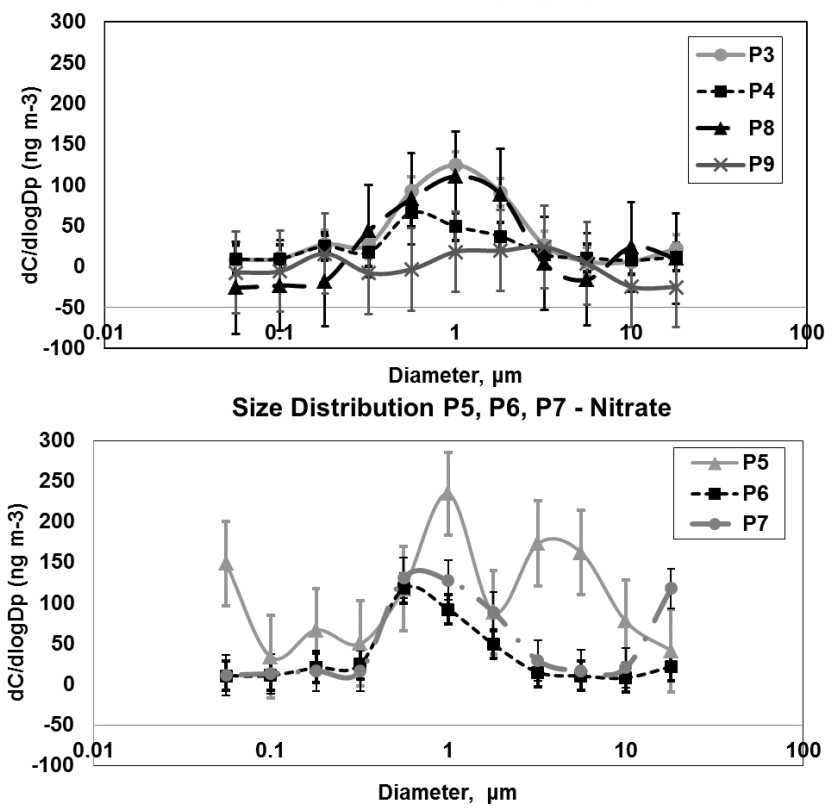

Fig. 6. Normalized size-segregated mass distribution of $\mathrm{NO}_{3}^{-}$during the sampling periods P1-P9.

from $\mathrm{SO}_{4}^{2-}$ and are generally found in the large particle fraction. This indicates that $\mathrm{Cl}^{-}$and $\mathrm{NO}_{3}^{-}$have more local origins. However, splitting the sampling period into three major episodes, reveals size distribution profiles more comparable for all the ions in air masses originating from west (P1 and P2), with less exposure to FYI. For these episodes the $\mathrm{NO}^{3-}$ and $\mathrm{Cl}^{-}$associated with particles $<1 \mu \mathrm{m}$ is dominating, which suggests that part of the $\mathrm{Cl}^{-}$and $\mathrm{NO}_{3}^{-}$is also long-range transported.

The particle mass size distributions of $\mathrm{Cl}^{-}$consist of at least 3 modes, with maxima at diameters of $D=0.56 \mu \mathrm{m}$, $1-1.8 \mu \mathrm{m}$ and $>18 \mu \mathrm{m}$. It is expected that the aerosols undergo transformation during their transport to Station Nord. $\mathrm{Cl}^{-}$in the fine fraction can originate from $\mathrm{Cl}^{-}$on coarser particles, which is released into the gas phase as $\mathrm{HCl}$ during transport, due to reactions between sea salt and acidic species like $\mathrm{HNO}_{3}$ or $\mathrm{H}_{2} \mathrm{SO}_{4}$ or their precursors (e.g. Barrie and Barrie, 1990; Hillamo et al., 1998; Fischer, 2001; Teinila et al., 2003; Quinn et al., 2009). The gas phase $\mathrm{HCl}$ can condense on smaller particles and in this way $\mathrm{Cl}^{-}$is redistributed from the coarse to the fine fractions.

A closer analysis of $\mathrm{Cl}^{-}$size distributions (Fig. 5) shows that during transport from Canada and west Greenland (P1 and $\mathrm{P} 2), \mathrm{Cl}^{-}$is mainly associated with long-range transported submicron particles, shifting to dominance of super micron particles when the air mass arrives directly from the sea ice (P3 and P4). Then the wind direction changes, and air masses are again transported along the coast from west Greenland, revealing a mixture of submicron and supermicron $\mathrm{Cl}^{-}$particles, with very coarse particles $(>18 \mu \mathrm{m})$ in $\mathrm{P7}$. The $\mathrm{Cl}^{-}$distributions change into dominance from super micron particles when the air mass again arrives from the frozen ocean (P8 and P9). The observed mass concentrations of $\mathrm{Cl}^{-}$in the different size regimes could be caused by redistribution, as explained above, during transport across the ice-covered ocean, combined with new contribution of aerosols/gases from frost flowers and refreezing leads. This is consistent with the more varying size distribution for the samples P3, P4, P8 and P9, where the air mass has been transported over sea ice for a longer time and, according to HYSPLIT back trajectories, had less vertical mixing. It has been suggested by Wolff et al. (2003) that frost flowers can contribute to wind transport of sea salt and Domine et al. (2004) found wind transported $\mathrm{Cl}^{-}$from open sea to snow. However, the measurements by Domine et al. (2004) were carried out in areas with a short distance to open water. The sample collected from 20 to 22 March (P7) revealed a large amount of $\mathrm{Cl}^{-}$on the very coarse particles. On 20 March the wind speed was high and the air mass was transported over sea ice. These very coarse particles can only originate from local sources as their sedimentation velocity does not allow transport over thousands of kilometres. We hypothesize that $\mathrm{Cl}^{-}$on the very coarse particles originates from frost flowers possibly torn at high wind speeds. Roscoe et al. (2011) found that frost flowers grown in the laboratory do not break even at high wind speeds $\left(12 \mathrm{~m} \mathrm{~s}^{-1}\right)$, but the atmospheric humidity in the laboratory experiments was not low as in the Arctic, and there were no blowing snow, or other particles, in the laboratory tank either. Another possible explanation could be that $\mathrm{Cl}^{-}$is taken up by wind blown snow when the air mass is passing over frost flowers or over brine from the ice surface. Yang et al. (2008) and Obbard et al. (2009) also suggested this to be a more likely mechanism than tearing of frost flowers.

The size distributions of $\mathrm{NO}_{3}^{-}$are dominated by at least 4 modes with maxima at geometric mean diameter of $D_{\mathrm{g}}=$ $0.18 \mu \mathrm{m}, 0.56-1.8 \mu \mathrm{m}, 3.2-5.6 \mu \mathrm{m}$, and $>18 \mu \mathrm{m}$. Over the oceans the particle mass size distribution of $\mathrm{NO}_{3}^{-}$typically follows the surface area distribution of sea salt (Prospero, 2002). Like $\mathrm{SO}_{4}^{2-}$ and $\mathrm{Cl}^{-}$the fine mode of $\mathrm{NO}_{3}^{-}$is likely to originate from long-range transport, and mass contributions in the coarser size regime to originate from local sources. Recent studies by Douglas et al. (2012) show high $\mathrm{NO}_{3}^{-}$ concentrations in frost flowers and surface brine, suggesting 


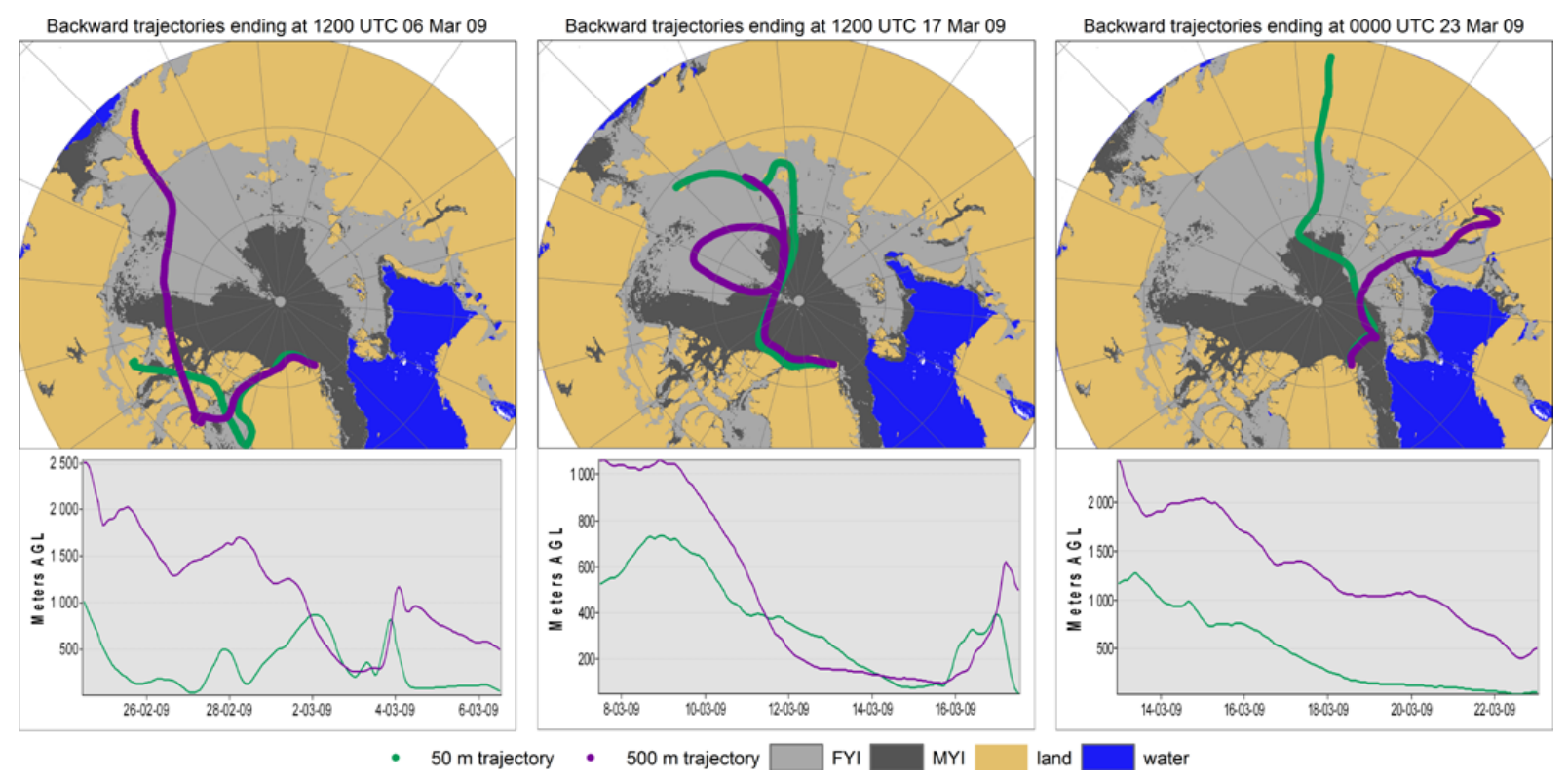

Fig. 7. Air mass back trajectories from the model HYSPLIT. The back trajectories are calculated for arrival at $50 \mathrm{~m}$ and $500 \mathrm{~m}$ a.s. 1. every $12 \mathrm{~h}$. The trajectories are shown for three typical cases: (a) west of Station Nord, (b) along the coast of North Greenland and (c) north of Station Nord. For spatial reference the corresponding sea ice coverage and the continents are provided as background maps, showing first-year-ice (FYI) and multi-year-ice (MYI) listed in Table 1.

that $\mathrm{NO}_{3}^{-}$can be emitted from frost flowers or simply from the ice surface. In contrast to $\mathrm{Cl}^{-}$and $\mathrm{SO}_{4}^{2-}, \mathrm{NO}_{3}^{-}$shows a significant mode in the size regime $D_{\mathrm{g}}=3.2-5.6 \mu \mathrm{m}$ between 16 and 17 March (P5). During these days the wind was higher than average $\left(7-9 \mathrm{~m} \mathrm{~s}^{-1}\right)$, which may be too low to destroy frost flowers, but could influence the snowpack, leading to enhanced emissions from the snowpack. According to Domine and Shepson (2002) and Douglas et al. (2012) the snow contains $\mathrm{NO}_{3}^{-}$; thus $\mathrm{NO}_{3}^{-}$could be released directly as particles in wind blown snow under conditions with increasing wind speeds. However $\mathrm{Cl}^{-}$is also found at elevated concentrations in the surface snow over sea ice (Douglas et al., 2012) and if the increased $\mathrm{NO}_{3}^{-}$concentration in the larger particles were due to wind blown snow we would expect an increase in $\mathrm{Cl}^{-}$concentration in this size range as well. According to Grannas et al. (2007) high concentrations of $\mathrm{NO}_{\mathrm{x}}\left(\mathrm{NO}_{2}+\mathrm{NO}\right)$ can be found in the snowpack. It is possible that $\mathrm{NO}_{2}$ is emitted from the snow due to wind pumping at high wind speed followed by oxidation in the atmosphere producing gaseous $\mathrm{HNO}_{3}$. The $\mathrm{HNO}_{3}$ is then taken up by sea salt particles forming $\mathrm{NO}^{-3}$ in the larger particle fraction and depleting $\mathrm{Cl}^{-}$as $\mathrm{HCl}$ (Rankin and Wolff, 2003). Prior to episode $\mathrm{P} 5$, the $\mathrm{NO}_{\mathrm{x}}$ concentration in the atmosphere was increased (see Fig. 3), thus we hypothesize that these processes can be a potential explanation for the higher concentration of $\mathrm{NO}_{3}^{-}$relative to $\mathrm{Cl}^{-}$associated with the large particle fraction.

\section{Conclusions}

The primary objective of this study was to improve the current understanding of composition and origin of Arctic aerosols through analysis of mass size distributions of major anions in late winter Arctic aerosols at Station Nord, northeast Greenland. It was found that aerosols in late winter/early spring just after polar sunrise are a mixture of longrange transported and regional to locally originating aerosols. Fine particles, smaller than $1 \mu \mathrm{m}$ containing $\mathrm{SO}_{4}^{2-}, \mathrm{Cl}^{-}$and $\mathrm{NO}_{3}^{-}$, most probably originate from long-range transport, which appears to be the most important source of major inorganic anions at Station Nord, where $\mathrm{SO}_{4}^{2-}$ is by far dominating, accounting for $50-85 \%$ of the analyzed mass. The analysis suggests that $\mathrm{Cl}^{-}$and $\mathrm{NO}_{3}^{-}$in coarser particles $(>1.5 \mu \mathrm{m})$ originate from local/regional sources. Under conditions where the air mass is transported over sea ice at high wind speeds, very coarse particles $(>18 \mu \mathrm{m})$ are found, and it is hypothesized that frost flowers on the sea ice are a potential source to $\mathrm{Cl}^{-}$and $\mathrm{NO}_{3}^{-}$particles. This is supported by Shaw et al. (2010), who found that particles in the Arctic in winter clearly had a sea spray profile despite the frozen polar ocean. The uncertainties of the $\mathrm{NO}_{3}^{-}$sources are still substantial and further studies on nitrogen processes in the high Arctic are needed.

\section{Supplementary material related to this article is available online at: http://www.atmos-chem-phys.net/13/ 1569/2013/acp-13-1569-2013-supplement.zip.}


Acknowledgements. This work was financially supported by the Aarhus University Research Foundation and The Danish Environmental Protection Agency with means from the Dancea funds for environmental support to the Arctic Region (Grant no M 112 00270). The findings and conclusions presented here do not necessarily reflect the views of the Agency. The Royal Danish Air Force is gratefully acknowledged for providing transport to Station Nord and the authors wish in particular to thank the staff at Station Nord for excellent support during sampling. The presented study is part of the Nordic Centre of Excellence CRAICC.

Edited by: J. W. Bottenheim

\section{References}

ACIA (Arctic Climate Impact Assessment): Overview Report, Cambridge Univ. Press, Cambridge, 140 pp., 2004.

Barrie, L. A. and Barrie, M. J.: Chemical-Components of Lower Tropospheric Aerosols in the High Arctic - 6 Years of Observations, J. Atmos. Chem., 11, 211-226, 1990.

Barrie, L. A. and Hoff, R. M.: The oxidation rate and residence time of sulphur dioxide in the Arctic atmosphere, Atmos. Environ., 18, 2711-2722, 1984.

Barrie, L. A., Hoff, R. M., and Daggupaty, S. M.: The influence of mid-latitudinal pollution sources on haze in the Canadian arctic, Atmos. Environ., 15, 1407-1419, 1981.

Domine, F. and Shepson, P. B.: Air-snow interactions and atmospheric chemistry, Science, 297, 1506-1510, 2002.

Domine, F., Sparapani, R., Ianniello, A., and Beine, H. J.: The origin of sea salt in snow on Arctic sea ice and in coastal regions, Atmos. Chem. Phys., 4, 2259-2271, doi:10.5194/acp-4-2259-2004, 2004.

Douglas, T. A. and Sturm, M.: Arctic haze, mercury and the chemical composition of snow across northwestern Alaska, Atmos. Environ., 38, 805-820, 2004.

Douglas, T. A., Domine, F., Barret, M., Anastasio, C., Beine, H. J., Bottenheim, J., Grannas, A., Houdier, S., Netcheva, S., Rowland, G., Staebler, R., and Steffen, A.: Frost flowers growing in the Arctic ocean-atmosphere-sea ice-snow interface: 1. Chemical composition, J. Geophys. Res., 117, D00R09, doi:10.1029/2011JD016460, 2012.

ESRI: ArcGIS Desktop: Release 10. Redlands, CA: Environmental Research Institute, 2011.

Fischer, H.: Imprint of large-scale atmospheric transport patterns on sea-salt records in northern Greenland ice cores, J. Geophys. Res.-Atmos., 106, 23977-23984, 2001.

Flyger, H., Heidam, N. Z., Hansen, K. A., Rasmussen, L., and Megaw, W. J.: The background levels of the summer tropospheric aerosol and trace gases in Greenland, J. Aerosol Sci., 11, 95-110, 1980.

Frossard, A. A., Shaw, P. M., Russel, L. M., Kroll, J. H., Canagaratna, M. R., Worsnop, D. R., Quinn, P. K., and Bates, T. S.; Springtime Arctic haze contributions of submicron organic particles from European and Asian combustion sources, J. Geophys. Res., 116, D05205, doi:1029/2010JD015178, 2011.

Glasow, R. von and Crutzen, P. J.: Tropospheric Halogen Chemistry in: The Atmosphere, edited by: Russel and Keeling, ISBN:9780080450919, Elsevier, 2007.
Gong, S. L., Zhao, T. L., Sharma, S., Toom-Sauntry, D., Lavoué, D., Zhang, X. B., Leaitch, W. R., and Barrie, L. A.: Identification of trends and interannual variability of sulfate and black carbon in the Canadian High Arctic: 1981-2007, J. Geophys. Res., 115, D07305, doi:10.1029/2009JD012943, 2010.

Grannas, A. M., Jones, A. E., Dibb, J., Ammann, M., Anastasio, C., Beine, H. J., Bergin, M., Bottenheim, J., Boxe, C. S., Carver, G., Chen, G., Crawford, J. H., Dominé, F., Frey, M. M., Guzmán, M. I., Heard, D. E., Helmig, D., Hoffmann, M. R., Honrath, R. E., Huey, L. G., Hutterli, M., Jacobi, H. W., Klán, P., Lefer, B., McConnell, J., Plane, J., Sander, R., Savarino, J., Shepson, P. B., Simpson, W. R., Sodeau, J. R., von Glasow, R., Weller, R., Wolff, E. W., and Zhu, T.: An overview of snow photochemistry: evidence, mechanisms and impacts, Atmos. Chem. Phys., 7, 43294373, doi:10.5194/acp-7-4329-2007, 2007.

Haywood, J. and Boucher, O.: Estimates of the direct and indirect radiative forcing due to troposheric aerosols: A review, Rev. Geophys., 38, 513-543, doi:10.1029/1999RG000078, 2000.

Heidam, N. Z., Wåhlin, P., and Christensen, J. H.: Tropospheric Gases and Aerosols in Northeast Greenland, J. Atmos. Sci., 56, 261-278, 1999.

Heidam, N. Z., Christensen, J., Wåhlin, P., and Skov, H.: Arctic atmospheric contaminants in NE Greenland: levels, variations, origins, transport, transformations and trends 1990-2001, Sci. Total Environ., 331, 5-28, 2004.

Hillamo, R., Allegrini, I., Sparapani, R., and Kerminen, V. M.: Mass size distributions and precursor gas concentrations of major inorganic ions in Antarctic aerosol, Int. J. Environ. An. Ch., 71, 353-372, 1998.

IPCC: Climate Change 2007: Contribution of Working Group I to the Fourth Assessment Report of the Intergovernmental Panel on Climate Change, edited by: Solomon, S., Qin, D., Manning, M., Chen, Z., Marquis, M., Averyt, K. B., Tignor, M., and Miller, H. L., Cambridge University Press, Cambrigde, UK and New York, NY, USA, 996 pp., 2007.

Jacobson, M. Z.: Strong radiative heating due to the mixing state of black carbon in atmospheric aerosols, Nature, 409, 695-697, 2001.

Jet Propulsion Laboratory (JPL): QuikSCAT Science Data Product, User Manual. Version 3.0, California Institute of Technology, September 2006.

Kanamitsu, M., Ebisuzaki, W., Woollen, J., Yang, S. K., Hnilo, J. J., Fiorino, M., and Potter, G. L.: Ncep-Doe Amip-Ii Reanalysis (R-2), B. Am. Meteorol. Soc., 83, 1631-1643, 2002.

Kawamura, K., Narukawa, M., Li, S. M., and Barrie, L. A.: Size distributions of dicarboxylic acids and inorganic ions in atmospheric aerosols collected during polar sunrise in the Canadian high Arctic, J. Geophys. Res.-Atmos., 112, D10307, doi:1029/2006JD008244, 2007.

Li, S. M. and Barrie, L. A.: Biogenic Sulfur Aerosol in the Arctic Troposphere .1. Contributions to Total Sulfate, J. Geophys. Res.Atmos., 98, 20613-20622, 1993.

Lungu, T. (Ed.): QuickSCAT Science Data Product, User's Manual, Version 2.2, D-18053; Jet Propulsion Laboratory, California Institute of Technology, 2001.

Nguyen, Q. T., Skov, H., Sørensen, L. L., Jensen, B. J., Grube, A. G., Massling, A., Glasius, M., and Nøjgaard, J. K.: Source apportionment of particles at Station Nord, North East Greenland during 2008-2010 using COPREM and PMF analysis, Atmos. 
Chem. Phys., 13, 35-49, doi:10.5194/acp-13-35-2013, 2013.

Obbard, R. W., Roscoe, H. K., Wolff, E. W., and Atkinson, H.: Frost flower surface area and chemistry as a function of salinity and temperature, J. Geophys. Res., 114, D20305, doi:10.1029/2009JD012481, 2009.

Polissar, A. V., Hopke, P. K., and Harris, J. M.: Source regions for atmospheric aerosol measured at Barrow, Alaska, Environ. Sci. Technol., 35, 4214-4226, 2001.

Prospero, J. M.: The chemical and physical properties of marine aerosols: An introduction: Springer-Verlag Berlin, Berlin, Germany, 82 pp., 2002.

Quinn, P. K., Miller, T. L., Bates, T. S., Ogren, J. A., Andrews, E., and Shaw, G. E.: A 3-year record of simultaneously measured aerosol chemical and optical properties at Barrow, Alaska, J. Geophys. Res.-Atmos., 107, 4130, doi:10.1029/2001JD001248, 2002.

Quinn, P. K., Shaw, G., Andrews, E., Dutton, E. G., Ruoho-Airola, T., and Gong, S. L.: Arctic haze: current trends and knowledge gaps, Tellus B, 59, 99-114, 2007.

Quinn, P. K., Bates, T. S., Baum, E., Doubleday, N., Fiore, A. M., Flanner, M., Fridlind, A., Garrett, T. J., Koch, D., Menon, S., Shindell, D., Stohl, A., and Warren, S. G.: Short-lived pollutants in the Arctic: their climate impact and possible mitigation strategies, Atmos. Chem. Phys., 8, 1723-1735, doi:10.5194/acp8-1723-2008, 2008.

Quinn, P. K., Bates, T. S., Schulz, K., and Shaw, G. E.: Decadal trends in aerosol chemical composition at Barrow, Alaska: 19762008, Atmos. Chem. Phys., 9, 8883-8888, doi:10.5194/acp-98883-2009, 2009.

Rankin, A. M. and Wolff, E. W.: A year-long record of sizesegregated aerosol composition at Halley, Antarctica, J. Geophys. Res., 108, 4775, doi:10.1029/2003JD003993, 2003.

Rankin, A. M., Wolff, E. W., and Martin, S.: Frost flowers: Implications for tropospheric chemistry and ice core interpretation, J. Geophys. Res.-Atmos., 107, 4683, doi:10.1029/2002JD002492, 2002 .
Roscoe, H. K., Brooks, B., Jackson, A. V., Smith, M. H., Walker, S. J., Obbard, R. W., and Wolff, E. W.: Frost flowers in the laboratory: Growth, characteristics, aerosol, and the underlying sea ice, J. Geophys. Res., 116, D12301, doi:10.1029/2010JD015144, 2011.

Seinfeld, J. H. and Pandis, S. N.: Atmospheric Chemistry and Physics - From Air Pollution to Climate Change, 2nd Edn., Wiley, 2006.

Shaw, P. M., Russell, L. M., Jefferson, A., and Quinn, P. K.: Arctic organic aerosol measurements show particles from mixed combustion in spring haze and from frost flowers in winter, Geophys. Res. Lett., 37, L10803, doi:10.1029/2010GL042831, 2010.

Swietlicki, E., Hansson, H. C., Hameri, K., Svenningsson, B., Massling, A., McFiggans, G., McMurry, P. H., Petaja, T., Tunved, P., Gysel, M., Topping, D., Weingartner, E., Baltensperger, U., Rissler, J., Wiedensohler, A., and Kulmala, M.: Hygroscopic properties of submicrometer atmospheric aerosol particles measured with H-TDMA instruments in various environments - a review, Tellus B, 60, 432-469, 2008.

Teinila, K., Hillamo, R., Kerminen, V. M., and Beine, H. J.: Aerosol chemistry during the NICE dark and light campaigns, Atmos. Environ., 37, 563-575, 2003.

Wallace, J. M. and Hobbs, P. V.: Atmospheric Science - An Introductory Survey, Academic Press, Elsevier, 2006.

Wolff, E. W., Rankin, A. M., and Rothlisberger, R.: An ice core indicator of Antarctic sea ice production, Geophys. Res. Lett., 30, 2158, doi:10.1029/2003GL018454, 2003.

Yang, X., Pyle, J. A., and Cox, R. A.: Sea salt aerosol production and bromine release: role of snow on sea ice, Geophys. Res. Lett., 35, L16815, doi:10.1029/2008GL034536, 2008. 